УДК 930.22

DOI: https://doi.org/10.31470/2518-7600-2020-9-131-149

DOCUMENTATION SCIENCE AS A SCIENTIFIC AND EDUCATIONAL DISCIPLINE IN MODERN UKRAINE: WHAT ARE THE WAYS OF DEVELOPMENT?

\title{
ДОКУМЕНТОЗНАВСТВО ЯК НАУКОВА І НАВЧАЛЬНА ДИЦИПЛІНА В СУЧАСНІЙ УКРАЇНІ: ЯКІ ШЛЯХИ РОЗВИТКУ?
}

\section{ДОКУМЕНТОВЕДЕНИЕ КАК НАУЧНАЯ И УЧЕБНАЯ ДИСЦИПЛИНА В СОВРЕМЕННОЙ УКРАИНЕ: КАКИЕ ПУТИ РАЗВИТИЯ?}

Сергій Кулешов,

доктор історичних наук,

професор кафедри суспільних наук,

інформаційної та архівної справи posena@ukr.net

ORCID: 0000-0003-1950-9651

Центральноукраӥнський національний

технічний університет

Кропивницький, Украӥна

\section{Вікторія Барабаш}

кандидат педагогічних наук,

доцент кафедри суспільних наук, інформачійної та архівної справи viktoria-k67@ukr.net

ORCID: 0000-0002-8560-0851

Центральноукраӥнський

національний

технічний університет

Кропивницький, Україна
Serhii Kuleshov,

Doctor of History, (Dr. habil.)

Professor of the Departament of

Social Sciences, Information and

Archival Affairs

posena@ukr.net

ORCID: 0000-0003-1950-9651

Central Ukrainian National

Technical University

Kropyvnytskyi, Ukraine

Viktoria Barabash,

Candidate of Pedagogical

Sciences,

Associate Professor of the Department of Public

Sciences, Information and Archival. viktoria-k67@ukr.net

ORCID: 0000-0002-8560-0851

Central Ukrainian National

Technical University

Kropyvnytskyi, Ukraine 


\section{ABSTRACT}

Now, documentation science in Ukraine is deprived of the status of a scientific discipline in the official list of scientific specialties, the number of scientific forums and, consequently, publications devoted to its scientific problems has been reduced, and a university documentary educational specialty has been eliminated. According to the author, the forerunner to this was the processes associated with the formation in Ukraine of two versions of documentation science - «documentological» («library documentation science») and classical (based on the ideas of the 1960-1970s, the famous Soviet archivist K. G. Mityaev). In the 1990 s, when the scientific status of documentation science was not officially approved in Ukraine, the documentological version was progressive. However, after the official approval of the scientific specialty "Documentation Sciences, Archival Studies》 in the framework of historical science (2001), supporters of documentology began the struggle for the formal separation of these sciences from special branches of historical science, which ended with their joining the disciplines within the scientific specialty «Social Communications» (2008). Dissemination of documentologe views in Ukrainian universities within the framework of the new specialty «Information, Library, Archival» leads to the dominance of library science over archival studies, a decrease in the number of hours of the course "Archival Studies» (compared to library science, its reading is much more complicated and much less specialists). Hence the actual leveling or disappearance of documentary courses. It is indisputable that the "abolition» of classical documentation science did not remove the practical needs for studies of the legal and methodological support for the organization of the sphere of archival business and paperwork. These studies in the modern conditions of implementation and functioning of electronic document management, the creation of electronic archives require, within these areas, a review of the organization of traditional office work and archive processes. On the other hand, there is an urgent need to harmonize these processes 
with the norms of international standards for the management of documentary processes. The article provides examples of recent developments in the field of documentation science and the organization of university education in Ukraine, which can be considered the most promising areas in the development of this scientific discipline.

Keywords: documentation science, archival science, scientific discipline, academic discipline, documentology, development directions.

Постановка проблеми. Вилучення документознавства 3 офіційного переліку наукових дисциплін не зняло необхідності здійснювати наукові дослідження 3 вирішення практичних проблем організації традиційного та електронного діловодства, інших напрямів у межах керування документаційними процесами. Зрозуміло, що традиційні центри документознавчих досліджень продовжують опрацювання профільної проблематики, здійснюються за дозволом Міністерства освіти і науки України захисти докторських та кандидатських дисертацій зі спеціальності «документознавство, архівознавство», існують вітчизняні плани гармонізації міжнародних нормативних документів у сфері «Інформація і документація». Однак виконанню в подальшому дослідницьких планів 3 документознавства буде перешкоджати відсутність вишівської підготовки документознавців та підвищення їхньої кваліфікації (аспірантура, докторантура 3 відновленої спеціальності «документознавство, архівознавство»). Таке навчання має здійснюватися у тісному зв'язку з архівознавством та архівною справою, з якими генетично пов'язані документознавство i діловодство.

Аналіз останніх досліджень і публікацій. Різні аспекти функціонування документознавства та перспективи документознавчої освіти розглянуто в публікаціях професорки В. Бездрабко (Бездрабко, 2020; 2019; 2018 та ін.). Новітнє 
бачення змісту документології висвітлено в працях професорки Г. Швецової-Водки (Швецової-Водка 2018; 2018). Питання розвитку класичного документознавства порушені в тезах завідувачки відділу документознавства Українського НДІ архівної справи та документознавства В. Бойко (Бойко, 2017). Проблематику, пов'язану з електронним документознавством і електронним діловодством, проаналізовано в статті Я. Калакури та Ю. Ковтанюка (Калакура, Ковтанюк, 2019) та в публікації Т. Клименко (Клименко, 2018).

Мета статті. Показати наявність документознавчих досліджень в останні роки, незважаючи на вилучення документознавства зі списку наукових дисциплін, а також прикладів раціонального збереження курсів документознавства у вишівському навчальному процесі.

Виклад основного матеріалу дослідження. Нині документознавство в Україні переживає скрутні часи, його позбавили статусу наукової дисципліни у переліку наукових спеціальностей, скоротилася кількість наукових форумів, присвячених його науковим проблемам, а відповідно, i публікацій, ліквідовано вишівську документознавчу навчальну спеціальність. Безперечно, така участь спіткала не тільки документознавство: в результаті укрупнення наукових спеціальностей навіть генетично пов'язане 3 ним архівознавство урізане до рівня «архівної справи» і разом 3 інформаційною та бібліотечною справою утворює блок інформаційних дисциплін. У цьому ми фактично повернулися до радянського переліку наукових спеціальностей. Але якщо в СРСР документознавство та архівознавство розглядали як окремі і взаємопов'язані дисципліни і не підлягав сумнівам їх зв'язок з історичною наукою, то тепер вони внесені у комплексну галузь знань «культура». Всі ці процеси пов’язані 3 формуванням двох версій документознавства в Україні «документологічної» (бібліотекознавче документознавство) та класичної (що грунтується на ідеях 1960 - 1970-х років відомого радянського архівознавця К. Мітяєва). Слід 
зауважити, що документологія як наукова дисципліна офіційно не була визнана, a iii прихильники - це, переважно, бібліотекознавці та викладачі вишів.

Вони намагалися створити нові навчальні курси (в умовах зменшення реальних наукових проблем бібліотечної справи) шляхом обгрунтування наукових напрямів на підставі формування загальної теорії документа для так званих дисциплін документально-комунікаційного циклу, що мали об’єднати бібліотекознавство, бібліографознавство, наукову інформатику, класичне (так зване «мітяївське») документознавство та архівознавство. Засадою об'єднавчих тенденцій була подібність основних термінів, що використовуються в цих дисциплінах - «документ», «документація», «документальний фонд», «забезпечення збереженості документів», «індексування документів» тощо. Саме бібліотекознавцями було сформовано навчальну вишівську спеціальність «Документознавство та інформаційна діяльність», що мала підкреслювати зв'язки документознавства з бібліотекознавством, бібліографознавством, науковою (або соціальною) інформатикою. Зусиллями переважно російського бібліотекознавця Ю. Столярова та українського бібліографознавця Г. Швецової-Водки сформувалася власне загальна теорія документа, що стала основою документології, однак вона жодним чином не пов'язана 3 практичними частинами тих наук, що є складниками «документальнокомунікаційного циклу». У 1990-і роки, коли в Україні не був офіційно утверджений науковий статус документознавства, ця версія була прогресивною. Однак, після офіційного затвердження наукової спеціальності «документознавство, архівознавство» у межах історичної науки (2001 р.), прихильниками документології почалася боротьба за офіційний відрив цих наук від спеціальних галузей історичної науки, яка завершилася внесенням їх до сукупності дисциплін у межах наукової спеціальності «соціальні комунікації» (2008 p.). 
Але тогочасні і сучасні українські документологи спираються не тільки на вітчизняну практику. В Свропі ще 3 1920-х років під впливом праць Поля Отле та інших діячів Міжнародного бібліографічного інституту сформувалася документаційна наука (дуже близька до розуміння комплексу наук документально-комунікаційного циклу) і нині їі представники відобразили у міжгалузевому міжнародному стандарті ISO 5127 - 2001 узагальнені формулювання базових понять документознавства. Цей стандарт було гармонізовано в Україні у 2017 році.

Поширення в українських вишах поглядів документологів у межах чинної навчальної спеціальності «інформаційна, бібліотечна, архівна справа» (ця згубна для документознавства сукупність теж асоціюється 3 практикою Західної Свропи, коли навчання у вишах 3 архівознавства відбувається разом з бібліотечною спеціальністю або навіть в ii межах) призводить до панування бібліотекознавства над архівознавством, зменшення частки годин архівознавства у навчальному процесі (порівняно з бібліотекознавством його читання набагато складніше та й фахівців доволі менше). Звідси фактичне нівелювання або зникнення документознавчих курсів.

Найдоцільнішою формою викладання у вишах документознавства у межах спеціальності «інформаційна, бібліотечна та архівна справа» було б розмежування його між навчальними дисциплінами «Бібліотекознавство» та «Архівознавство». В навчальному курсі «Бібліотекознавство» можна було б розглядати основи документології, а в курсі «Архівна справа» - засади класичного докуменознавства й діловодства. Це власне повертало б нас до початкового етапу історії документознавства у радянські часи, яке існувало як пропедевтична дисципліна до навчального курсу архівної справи. Оскільки архівна справа генетично пов'язана 3 класичним («мітяєвським») документознавством.

Може скластися уявлення, що автори негативно 
ставляться до документології. Нi, навпаки, ми вважаємо, що як i на початку 1990-х років, розробки в їі напрямах мають позитивний ефект у стимулюванні інтересу до феномена документа та процесів формування загальної теорії документа. Особливу роль в Україні відіграють праці з документології професорки Г. Швецової-Водки (Швецова-Водка, 2018; Бездрабко, 2019) та низка публікацій з історії та сучасного стану документознавства в Україні та світі професорки В. Бездрабко (Бездрабко, 2009; Бездрабко, 2010). До того ж, проблематика документології нині знаходить (хоча іноді і досить гіпертрофованому вияві) зацікавленість і в Західній Європі. Взяти хоча б як приклад університет норвезького міста Тромсе, викладачі якого розвивають ідеї дуже близькі до бібліотечного документознавства i активно проводять міжнародні конференції 3 цього напряму і публікують їх матеріали у так званих працях Академії документів (The Proceedings from the Document Academy, Volume 6, Issue 1, 2019). Їх дослідження значною мірою асоціюються 3 так званою документаційною наукою 1950 - 1960-х рр. (самі вони називають іiі «нео-документацією»), що була результатом розробок вже згадуваного Поля Отле. Цікавими $є$ також публікації відомого російського документознавця Є. Плешкевича, який в останні роки 3 позицій двох версій документознавства розвиває власні положення теорії документальної (документної) інформації (Плешкевич, 2015; 2016, Швецова-Водка, 2015). Їх зміст певною мірою $\epsilon$ продовженням формування інформаційної концепції документознавства, яку свого часу задекларував, на жаль нині покійний, відомий український вчений професор М. Слободяник.

Електронне документознавство є складником розробок як у сфері діловодства, так і у сфері архівної справи. У світовій практиці, якщо спрощено розглядати ситуацію 3 класичним документознавством, нині його проблематика увійшла до наукової дисципліни Records Management (керування 
документаційними процесами), хоча вона не охоплює всіх наукових питань, що були притаманні документознавству, до його офіційного вилучення в Україні з переліку наукових дисциплін.

Безперечно, таке вилучення не зняло практичних потреб в дослідженнях 3 нормативно-правового та методичного забезпечення організації сфери архівної справи та діловодства. Зазначені дослідження в сучасних умовах впровадження функціонування електронного документообігу та електронних архівів потребує узгодження у межах цих напрямів та перегляд організації традиційних діловодних та архівних процесів. 3 іншого боку, існує нагальна потреба узгодження зазначених процесів 3 нормами міжнародних стандартів 3 керування документаційними процесами.

Так, Технічний комітет стандартизації ТК 144 «Інформація і документація» схвалив рішення про розроблення у найближчі роки таких проектів національних нормативних документів (далі - НД) методом перекладу на заміну ДСТУ.

\begin{tabular}{|c|c|}
\hline Назви національних стандартів & На заміну \\
\hline $\begin{array}{l}\text { ДСТУ ISO 30300:2011 Інформація та } \\
\text { документація. Системи керування } \\
\text { документами. Основні положення і } \\
\text { словник термінів }\end{array}$ & $\begin{array}{l}\text { ДСТУ ISO 30300:2015 } \\
\text { (ISO 30300:2011, IDT) Інформація та } \\
\text { документація. Системи керування } \\
\text { документами. Основні положення і } \\
\text { словник термінів } \\
\end{array}$ \\
\hline $\begin{array}{l}\text { ДСТУ ISO 15489-1:2016 Інформація } \\
\text { і документація. Керування } \\
\text { документаційними процесами. } \\
\text { Частина 1. Поняття і принципи }\end{array}$ & $\begin{array}{l}\text { ДСТУ ISO 15489-1:2018 (ISO 15489- } \\
\text { 1:2016, IDT) Інформація та } \\
\text { документація. Керування записами. } \\
\text { Частина 1. Поняття та принципи } \\
\end{array}$ \\
\hline $\begin{array}{l}\text { ДСТУ ISO 23081-1:2017 Інформація } \\
\text { і документація. Керування } \\
\text { документаційними процесами. } \\
\text { Метадані щодо документації. } \\
\text { Частина 1. Принципи }\end{array}$ & $\begin{array}{l}\text { ДСТУ ISO 23081-1:2018 (ISO 23081- } \\
\text { 1:2017, IDT) Інформація та } \\
\text { документація. Процеси керування } \\
\text { записами. Метадані щодо записів. } \\
\text { Частина 1. Принципи }\end{array}$ \\
\hline $\begin{array}{l}\text { ДСТУ ISO 30302:2015 Інформація і } \\
\text { документація. Системи керування } \\
\text { документацією. Настанови щодо } \\
\text { впровадження }\end{array}$ & $\begin{array}{l}\text { ДСТУ ISO 30302:2018 (ISO } \\
\text { 30302:2015, IDT) Інформація та } \\
\text { документація. Системи керування } \\
\text { записами. Настанови щодо } \\
\text { впровадження }\end{array}$ \\
\hline
\end{tabular}


I хоча планові назви НД іноді містять не зовсім коректні переклади назв стандартів ISO у попередніх (тобто чинних) ДСТУ, зокрема, «системи керування документами» та «системи керування документацією» (має бути «системи керування документаційними процесами»), ці перспективи слід оцінити позитивно.

Дослідження 3 класичного документознавства продовжують здійснювати в нашій країні Державна архівна служба України, Український НДІ архівної справи та документознавства (далі - УНДІАСД), центральні та обласні державні архіви. Зрозуміло, що серед центральних архівів провідна роль у розробленні проблематики електронного документознавства залишається у Центрального державного електронного архіву України (далі - ЦДЕА). Головний часопис в Україні з архівної справи - «Архіви України» - продовжує публікувати статті, пов'язані 3 проблематикою документознавства.

В останні роки фахівці УНДІАСД здійснювали дослідження, на підставі яких розроблено:

«Примірну номенклатуру справ сільської (селищної) ради об’єднаної територіальної громади»; Проекти уніфікованих форм планово-звітної документації архівних установ України та рекомендації щодо їх складення і оформлення; «Методичні рекомендації 3 розроблення інструкції 3 діловодства юридичних осіб приватного права»; «Методичні рекомендації 3 проведення експертизи цінності та відбору на архівне зберігання документів, пов'язаних із соціальним захистом громадян». Інститутом було завершено підготовку проекту нової редакції ДКУД. Фахівці інституту продовжують публікувати статті 3 актуальних питань класичного документознавства (Бойко 2016; 2017; Загорецька, 2017; Свердлик, 2017; 2018).

Водночас спільно 3 ЦДЕА України розроблялася проблематика 3 електронного документознавства та спорідненого з ним електронного архівознавства, зокрема: 
- наукове обгрунтування та розроблення технологій комплектування архівних установ документами в електронній формі;

- концепція інформатизації архівної справи в Україні;

- дослідження теоретичних та практичних засад забезпечення збереженості електронних документів Національного архівного фонду.

У 2019 році до секретаріату ТК 144 надійшла друга редакція проекту національного стандарту ДСТУ 4163:20 «Державна уніфікована система документації. Уніфікована система організаційно-розпорядчої документації. Вимоги до оформлення документів», розробленого Укрдержархівом та УНДІАСД. Також фахівцями УНДІАСД завершено розроблення проекту національного стандарту ДСТУ 2732:20 «Діловодство й архівна справа. Терміни та визначення понять», але для надання на платне рецензування в Державне підприємство «Український науково-дослідний і навчальний центр проблем стандартизації, сертифікації та якості» в інституті відсутні кошти.

Вагомий внесок у розвиток класичного документознавства здійснює Національна бібліотека України iм. В. I. Вернадського. Крім розроблення проблематики його наукових напрямів, що здійснюється фахівцями Інституту рукопису та Інституту архівознавства, у межах бібліотеки продовжувала роботу спеціалізована рада із захисту дисертацій зі спеціальності «документознавство, архівознавство». В останні роки були успішно захищені дві докторські дисертації «Уніфікація та стандартизація документознавчої термінології в Україні» (О. Тур) та «Документально-інформаційні ресурси радянського руху Опору в Україні (1941-1944 рр.).» (Л. Ковальська), а також низка кандидатських дисертацій, зокрема 3 історичного документознавства (Т. Барабаш «Латинське письмо у міських канцеляріях Руського воєводства XVI - XVII ст.»); (3. Свердлик «Організація діловодства в думі та управі міст Києва (1870 - 1917 роки»), 
електронного документознавства (О. Вдовіна «Електронне діловодство як комунікаційна складова судочинства в Україні»), (К. Корнійчук «Формування системи електронного документообігу в транспортному комплексі України»), сучасних проблем підготовки та функціонування документації в різних сферах та галузях (Ю. Коротецька «Сучасний документаційний супровід діяльності православних релігійних організацій України»; Н. Філіппова Документно-інформаційні ресурси медичної галузі України: теоретичний та практичні аспекти»).

С вдалі приклади викладання документознавчих курсів в українських вишах. Зокрема, у межах підготовки бакалаврів зі спеціалізацій «Менеджмент архівної справи» та «Управління інформаційно-документаційною діяльністю» кафедра архівознавства та спеціальних галузей історичної науки Київського національного університету імені Тараса Шевченка (завідувачка кафедри д.і.н., професорка М. Палієнко) викладаються курси «Управлінське документознавство» ( $€$ основним складником класичного документознавства) та «Керування документаційними процесами». Фактично збережені основні документознавчі навчальні дисципліни у підготовці архівістів кафедрою документознавства та інформаційно-аналітичної діяльності Київського національного університету культури і мистецтв (завідувачка кафедри д.і.н. професорка В. Бездрабко). До таких кафедр також належить кафедра спеціальних дисциплін, інформаційної та архівної справи Центральноукраїнського національного технічного університету (завідувач кафедри д.і.н., професор В. Орлик).

Висновки та перспективи подальших досліджень теми. Таким чином, незважаючи на відсутність документознавства в офіційному переліку наукових дисциплін, головні осередки класичних документознавчих досліджень продовжують діяльність 3 розроблення його традиційної тематики. Опоненти класичного документознавства мають зрозуміти важливість зазначених розробок у межах як наукової 
галузі знань, так і навчальної спеціальності «Інформаційна, бібліотечна та архівна справа», оскільки без вирішення проблем організації документаційних процесів неможливе вирішення завдань архівної справи особливо в умовах впровадження електронних технологій в діловодстві та архівній справі. Однак виконанню в подальшому дослідницьких планів 3 документознавства буде перешкоджати відсутність вишівської підготовки документознавців та підвищення їхньої кваліфікації (аспірантура, докторантура у межах відновленої наукової спеціальності «документознавство, архівознавство»). Таке навчання має здійснюватися у тісному зв'язку 3 архівознавством та архівною справою, 3 якими генетично пов'язані документознавство і діловодство.

\section{ДЖЕРЕЛА ТА ЛІТЕРАТУРА}

1. Бездрабко В. В. Актуальні проблеми документознавства в Україні. Бібліотекознавство. Документознавство. Інформологія. 2020. № 1. С. 39-44.

2. Бездрабко В. Архівна освіта в Україні: стан і перспективи. Сумський історико-архівний журнал. 2018. Т. XXXI. С. 5-17.

3. Бездрабко В. Документознавство в Україні: інституціоналізація та сучасний розвиток: монографія. Київ: Четверта хвиля, 2009. 720 с.

4. Бездрабко В. Історіографічні ескізи про документознавство, або Персональний текст про персональні тексти. Київ: Четверта хвиля, 2010. 208 с.

5. Бездрабко В. Ноокомунікологія Галини Швецової-Водки. Вісник Книжкової палати. 2019. № 5. С. 46-51.

6. Бойко В. Актуальні питання розвитку сучасного документознавства в Україні . Термінологія документознавства та суміжних галузей знань : зб. наук. пр. / Київ. нац. ун-т культури і мистецтв, ф-т культурології, каф. інформ., бібл. та арх. справи ; за заг. ред. В. В. Бездрабко. Київ : Четверта хвиля, 2017. Вип. 10. С. 178-180. 
7. Бойко В. Ф. Розроблення нової редакції Класифікатора управлінської документації. Архіви України. 2016. Вип. 5-6. C. $153-158$.

8. Загорецька О. Бойко В. Основні результати дослідження документопотоків сільської (селищної) ради об'єднаної територіальної громади. Студіï з архівної справи та документознавства. 2017. Т. 24-25. С. 94-124.

9. Калакура Я. С., Ковтанюк Ю. С. Архівний менеджемент в умовах електронного урядування. Архіви України. 2019. Вип. 3. С. 18-57.

10. Клименко Т. А. Цифровізація процесів архівної справи та діловодства як пріоритет діяльності Державного архіву Черкаської області. Архіви України. 2018. Вип. 5-6. С. 22-26.

11. Плешкевич E. А. Документально-информационный подход в контексте методологии постнеклассического познания в библиографоведении и библиотековедении. Библиосфера. 2016. № 1. С. 3-9.

12. Плешкевич Е. А. Концепция социальных коммуникаций Никласа Лумана и теория документальной информации: точки пересечения. Научно-техническая информация. Сер. 2. Информационные прочессы и системы. 2016. № 9. С. 1-6.

13. Плешкевич Е. А. На пути к информационной картине мира Джеймса Глика. Сер. 2. Информационные прочессы и системы. 2015. № 5. С. 33-37.

14. Свердлик 3. М. Службове листування як форма ділової комунікації Київської міської думи й управи (кін. XIX - поч. XX ст.). Бібліотекознавство. Документознавство. Інформологія. 2017. № 2. С. 20-27.

15. Свердлик 3. М. Архівні документи як джерело дослідження документаційного забезпечення органів місцевого самоврядування. Бібліотекознавство. Документознавство. Інформологія. 2018. № 2. С. 39-44.

16. Швецова-Водка Г. Н. Документ в теории документальной информации Е. А. Плешкевича. Научно-техническая информачия. Сер. 1, Организачия и методика информачионной pаботы. 2015. № 1. С. 27-34. 
17. Швецова-Водка $\quad$ Г. $\quad$ H. Ноосферная тематика в документологии. Научные и технические библиотеки. 2018. № 9. С. 92-105.

\section{Електронні ресурси}

18. Current Issue: Volume 6, Issue 1 (2019) Proceedings from the 2019 Annual Meeting of the Document Academy - Mode of acces: URL: https://ideaexchange.uakron.edu/docam/ Title from screen. Actuality 06.07.2020.

\section{REFERENCES}

1. Bezdrabko, V. V. (2020). Aktual'ni problemy' dokumentoznavstva $\mathrm{v}$ Ukrayini [Current problems of documentation science in Ukraine] // Bibliotekoznavstvo. Dokumentoznavstvo. Informologiya, 1. 39-44. [in Ukrainian].

2. Bezdrabko, V. (2018). Arxivna osvita v Ukrayini: stan i perspekty'vy' [Archive education in Ukraine: state and prospects`vy] // Sums 'ky j istory 'ko-arxivny j zhurnal. XXXI, 517. [in Ukrainian].

3. Bezdrabko, V. (2009). Dokumentoznavstvo v Ukrayini: insty 'tucionalizaciya ta suchasny 'j rozvy'tok [Documentation science in Ukraine: institutionalization and modern development]: monografiya. Ky'yiv: Chetverta xvy 'lya, 720. [in Ukrainian].

4. Bezdrabko, V. (2010). Istoriografichni eskizy' pro dokumentoznavstvo, abo Personal 'ny j tekst pro personal 'ni teksty [Historiographical sketches about documentation science, or Personal text about personal texts]. Ky`yiv: Chetverta xvy`lya, 208. [in Ukrainian].

5. Bezdrabko, V. (2019). Nookomunikologiya Galy`ny’ Shveczovoyi-Vodky [Noocommunicology of Galina ShvetsovaVodka] // Visny 'k Kny zhkovoyi palaty. 5. 46-51 [in Ukrainian].

6. Bojko, V. (2017). Aktual’ni py`tannya rozvy'tku suchasnogo dokumentoznavstva v Ukrayini [Current issues of development of modern documentation science in Ukraine] // Terminologiya dokumentoznavstva ta sumizhny'x galuzej znan': zb. nauk. pr. Ky`yiv : Chetverta xvy`lya. 10. 178-180 [in Ukrainian]. 
7. Bojko, V. F. (2016). Rozroblennya novoyi redakciyi Klasy` fikatora upravlins koyi dokumentaciyi [Development of a new version of the Classifier of Management Documentation] // Arxivy 'Ukrayiny`. 5-6. 153-158 [in Ukrainian].

8. Zagorecz'ka, O. \& Bojko V. (2017). Osnovni rezul'taty' doslidzhennya dokumentopotokiv sil's 'koyi (sely'shhnoyi) rady' ob'yednanoyi tery'torial 'noyi gromady' [The main results of the study of document flows of the village (settlement) council of the united territorial community] // Studiyi z arxivnoyi spravy' ta dokumentoznavstva. 24-25. 94-124 [in Ukrainian].

9. Kalakura, Ya. S., Kovtanyuk, Yu.S. (2019). Arxivny’j menedzhement $\mathrm{v}$ umovax elektronnogo uryaduvannya [Archival management in terms of e-government] // Arxivy 'Ukrayiny. 3. 1857 [in Ukrainian].

10. Kly`menko, T. A. (2018). Cy`frovizaciya procesiv arxivnoyi spravy` ta dilovodstva yak priory'tet diyal’nosti Derzhavnogo arxivu Cherkas koyi oblasti [Digitization of archival and office work processes as a priority of the State Archives of Cherkasy region] // Arxivy`Ukrayiny. 5-6. 22-26 [in Ukrainian].

11. Pleshkevich, E. A. (2016). Dokumental'no-informacionnyj podhod $\mathrm{v}$ kontekste metodologii postneklassicheskogo poznanija $\mathrm{v}$ bibliografovedenii i bibliotekovedenii [A documentaryinformational approach in the context of the methodology of post-non-classical cognition in bibliography and library science] // Bibliosfera. 1, 3-9 [in Russian].

12. Pleshkevich, E. A. (2016). Koncepcija social'nyh kommunikacij Niklasa Lumana i teorija dokumental'noj informacii: tochki peresechenija [The concept of social communications by Niklas Luman and the theory of documentary information: intersection points] // Nauchno-tehnicheskaja informacija. Ser. 2. Informacionnye processy i sistemy. 9, 1-6 [in Russian].

13. Pleshkevich, E. A. (2015). Na puti k informacionnoj kartine mira Dzhejmsa Glika [On the way to the James Glick informational world picture] // Ser. 2. Informacionnye processy i sistemy. 5. 3337 [in Russian]. 
14. Sverdly`k, Z. M. (2017). Sluzhbove ly`stuvannya yak forma dilovoyi komunikaciyi Ky`yivs ‘koyi mis ‘koyi dumy` j upravy` (kin. XIX - poch. XX st.) [Business correspondence as a form of business communication of the Kyiv City Duma and council (late XIX - early XX centuries)] // Bibliotekoznavstvo. Dokumentoznavstvo. Informologiya. 2. 20-27 [in Ukrainian].

15. Sverdly`k, Z. M. (2018). Arxivni dokumenty` yak dzherelo doslidzhennya dokumentacijnogo zabezpechennya organiv miscevogo samovryaduvannya [Archival documents as a source of research of documentation support of local self-government bodies] // Bibliotekoznavstvo. Dokumentoznavstvo. Informologiya. 2. 39-44 [in Ukrainian].

16. Shvecova-Vodka G. N. (2015). Dokument v teorii dokumental'noj informacii E. A. Pleshkevicha [Document in the theory of documentary information E.A. Pleshkevich]// Nauchnotehnicheskaja informacija. Ser. 1, Organizacija i metodika informacionnoj raboty. 1. 27-34 [in Russian].

17. Shvecova-Vodka, G. N. (2018). Noosfernaja tematika v dokumentologii [Noosphere topics in documentology] // Nauchnye i tehnicheskie biblioteki. 9, 92-105 [in Russian].

\section{АНОТАЦІЯ}

Нині документознавство в Україні позбавлено статусу наукової дисципліни у офіційному переліку наукових спеціальностей, скоротилася присвячених його науковим проблемам кількість наукових форумів, а відповідно $i$ публікацій, ліквідовано вишівську документознавчу навчальну спеціальність. На думку авторів, попередньо иј процеси пов'язані з формуванням двох версій документознавства в Україні - «документологічної» («бібліотекознавчоӥ») та класичної (щуо трунтується на ідеях 1960 -1970-х років відомого радянського архівознавия $К$. Г. Мітяєва). У 1990-і роки, коли в Украӥні не було офіиійно утверджено науковий статус документознавства, документологічна версія була прогресивною. Однак після офіційного затвердження 
наукової спеціальності «документознавство, архівознавство» y межах історичної науки (2001р.), прихильниками документології почалася боротьба за офіційний відрив иүих наук від спеціальних галузей історичної науки, яка завериилася внесенням їх до сукупності дисциплін у межах наукової спеціальності «соціальні комунікації»(2008 р.). Поширення в українських вишах поглядів документологів у межах нової навчальної спеціальності «Інформаційна, бібліотечна, архівна справа» призводить до панування бібліотекознавства над архівознавством, зменшення частки годин курсу "Архівна справа» (порівняно з бібліотекознавством його читання набагато складніше та й фахівців доволі менше). Звідси фактичне нівелювання або зникнення документознавчих курсів. Безперечно, шуо «скасування» класичного документознавства не зняло практичних потреб в дослідженнях з нормативноправового та методичного забезпечення організачії сфери архівної справи та діловодства. Зазначені дослідження в сучасних умовах впровадження функиіонування електронного документообігу та електронних архівів потребує у межах цฺих напрямів перегляду організації традиційних діловодних та архівних процесів. 3 іншого боку, існує нагальна потреба узгодження зазначених прочесів з нормами міжнародних стандартів з керування документаційними процесами. У статті наведено приклади розробок з документознавства $i$ організачії вишівського навчання в Україні, які можна вважати найбільш перспективними напрямами розвитку иүієі наукової дисичипліни.

Ключові слова: документознавство, архівознавство, наукова дисиипліна, навчальна дисципліна, документологія, напрями розвитку

\section{АННОТАЦИЯ}

Сейчас документоведение в Украине лишено статуса научной дисииплины в официильном перечне научных специальностей, сократилась, посвященных его научным 
проблемам, количество научных форумов, а соответственно и публикаций, ликвидировано вузовскую документоведческую учебную специальность. По мнению авторов, предтечей этому были процессы, связанные с формированием в Украине двух версий документоведения - «документологической» («библиотековедческой») и классической (основанной на идеях 1960 - 1970-х годов известного советского архивоведа К. Г. Митяева). В 1990-е годы, когда в Украине не был официально утвержден научный статус документоведения, документологическая версия была прогрессивной. Однако, после официального утверждения научной специальности «документоведение, архивоведение» в рамках исторической науки (2001 г.), сторонниками документологии началась борьба за офичиальный отрыв этих наук от спещиальных отраслей исторической науки, которая завершилась присоединением их к дисииплинам в рамках научной специиальности «социиальные коммуникации» (2008 г.). Распространение в украинских вузах взглядов документологов в рамках новой учебной специальности «информациинное, библиотечное, архивное дело» приводит $\kappa$ господству библиотековедения над архивоведением, уменьшением количества часов учебного курса «Архивное дело» (по сравнению с библиотечным делом его чтение гораздо сложнее и специиалистов гораздо меньше). Отсюда фрактическое нивелирование или исчезновение документоведческих курсов. Бесспорно, что «отмена» классического документоведения не сняла практических потребностей в исследованиях нормативно-правового и методического обеспечения организации сферы архивного дела и делопроизводства. Указанные исследования в современных условиях внедрения $и$ функционирования электронного документооборота, создания электронных архивов требует в рамках этих направлений пересмотра организациии традищионных делопроизводственных и архивных прочессов. С другой сторонь, существует настоятельная необходимость 
согласования указанных процессов с нормами межсународных стандартов по управлению документационными процеессами. В статье приведень примеры разработок последних лет в области документоведения и организации вузовского обучения в Украине, которье можно считать наиболее перспективными направлениями в развитии этой научной дисииплиньл.

Ключевые слова: документоведение, архивоведение, научная дисичплина, учебная дисичиллин, документология, направления развития. 